DOI: $10.1515 /$ rpp-2017-0031

Doctor of Philosophical Sciences, Full Professor, NATALIIA PETRUK

Khmelnytskyi National University, Ukraine Address: 11 Instytutska St., Khmelnytskyi, 29016, Ukraine E-mail: nataliia.petruk@gmail.com

\title{
THE INFLUENCE OF WESTERN EUROPEAN HUMANISTIC PEDAGOGY ON FORMING UKRAINIAN SCHOOL IN 16TH-17TH CENTURIES
}

\begin{abstract}
The article is dedicated to analysis of the content and the peculiarities of school education in Ukraine in view of disseminating the leading ideas of European humanistic pedagogy during the 16th-17th centuries. It has been noted that during the period of disseminating humanistic ideas the principles of Ukrainian education and Ukrainian school were forming in an active interaction with European culture and European education. Ukrainian school education is seen as a phenomenon that has accumulated the values of Western European humanistic culture, namely, respect for the individual, awareness of intellectual activity importance, the value of labour, understanding of the need for education and knowledge of languages. An active role in disseminating the pan-European models of education has been played by an intellectual environment, which was forming in the wellknown cultural and educational centers of Ukraine of the 16th-17th centuries, such as the Ostroh Culture and Education Center, the Lviv Brother School, the Kyiv Brother School, the Kyiv Collegium. Ukrainian intellectual elite, namely, university professors, teachers, students, have become the main carriers of education. The nature of the processes taking place in the educational space of Ukraine have been significantly influenced by the circumstances of religious life associated with the protection of the Orthodox Church before the onset of Catholicism. High standards of education, knowledge of the old classical and modern European languages were an important basis for the full-fledged spiritual development of the Ukrainian ethnic group. A retrospective consideration of the past reveals new meanings and imperatives in development of modern Ukrainian education, and the rich experience of Ukrainian teachers, collegium lecturers, professors of the first universities justify the necessary reasons for Ukrainian education entering into the European space.

Keywords: school education, humanism, education, academy, brother school,
\end{abstract} collegium, trivium, quadrivium.

\section{INTRODUCTION}

One of the main imperatives in development of Ukrainian education is the use of pedagogical experience of generations of Ukrainian teachers, collegium teachers, university professors, spiritual mentors and preachers. Ukrainian school education has its own deep tradition, uses a rich pedagogical heritage, which, in particular, was developed and dissiminated during the 16th-17th centuries. Then, humanistic influences and humanistic ideas from Europe, mainly from Poland, penetrated in Ukraine, humanistic pedagogy received new impetus for development. In an active interaction with European culture and European education, the foundations of Ukrainian education, Ukrainian school and high standards of pedagogical culture as a whole were formed. Due to dissemination of humanistic ideas, the attitude toward personality as a value, approbation of humanistic principles of activity in 
school work, the Ukrainian cultural and intellectual community participated in forming the pan-European cultural and educational space.

\section{THE AIM OF THE STUDY}

The aim of the paper is to study the history of forming school education in Ukraine and the influence of the ideas of humanistic pedagogy, originated in Western Europe, on this process.

\section{THEORETICAL FRAMEWORK AND RESEARCH METHODS}

Theoretical and methodological basis of the research consists of philosophical, historical and pedagogical, culturological and concrete scientific conclusions regarding development of pedagogical thought and formation of the educational culture in Ukraine during the 16 th- 17 th centuries.

The research is based on the works and historical documents, in which the state of Ukrainian education during the 16th-17th centuries was recorded. In particular, data on the activities of the Ostroh Culture and Education Center, the Zamois Academy are presented in such a fundamental collection of documents relating to various aspects of the spiritual life of Ukraine in the 16th and 17th centuries, such as the Acts Related to the History of Western Russia (1861-1892). The materials on the history of the Lviv and other brother schools in Ukraine are concentrated in the archival editions, namely, in the Archive of South-Western Russia (1859-1911), the Acts Related to the History of the Lviv-Stavropigial Brotherhood (1904), as well as in the work "Memorials of Brother Schools in Ukraine" (1988). In the anthology "Ukrainian Humanists of the Renaissance" (1995), there are published little-known, mostly Latin, works of prominent Ukrainian humanists, the figures of Ukrainian schools and colleges. Important sources for studying the content of philological training in Ukrainian schools are the first textbooks of the Slavic language, by P. Berynda ("The Slavic-Russian Lexicon, Kyiv, 1627), L. Zizanii Slavic Grammar, Wilno, 1590) and M. Smotrytskyi (Correct Syntagms of Slavic Grammar, 1619).

The paper is an example of an interdisciplinary, integral research on the outlined phenomenon. Based on various methodological approaches (historical and cultural, axiological, activity-based and personal), school education in Ukraine is considered in the dynamics of development of its forms and manifestations.

\section{RESULTS}

The introduction of school education in Ukraine has become one of the consequences of formation of the humanistic and reformational culture in Europe. This was facilitated by the intellectual environment, which was actively formed in the areas of Ukrainian culture, education and science. It is about the Ukrainian intellectuals, teachers, university professors, students who are the main carriers of education and erudition in the 16th-17th centuries.

The multifaceted actions of Ukrainian humanists who promoted high-quality examples of European culture among compatriots were aimed at the induvidual and helped to establish their activity, including intellectual, in various spheres of life, namely, in education, in school affairs, etc. In general, this proved penetration of European humanist influences into the intellectual and literary elite. Ukrainian consciousness of the 16th-17th centuries was aimed at percepting the new; it synthesized Western ideas with a purely national content of the process of upbringing and school education.

The Renaissance was the era in the history of European culture, which changed not only different spheres of European life - from political to educational, but also influenced development of many Eastern European cultures, including Ukrainian. During the 16th-17th centuries, Ukraine was influenced by Renaissance ideas, and, consequently, in Ukrainian 
education one could observe phenomena and processes of the Renaissance origin and nature. The peculiarity of the Renaissance culture and its humanistic consciousness was expressed in the birth of a new outlook that opposed the medieval system of thinking, namely, treating the individual as the subject of creative activity, the result of which were changes in science, education and art. In the East Slavic, Ukrainian world, the Renaissance found a rather peculiar embodiment, since humanistic consciousness was interwoven with the manifestations of Christian thinking.

In Ukraine, philological studies acquired new Renaissance forms, rhetoric was associated with solving ethical and humanistic tasks, humanistic pedagogy originated, which was primarily oriented toward upbringing. Undoubtedly, the Renaissance elements in the Ukrainian spiritual, educational and school life could not develop to the level of the national Renaissance culture, such as in Italy or Germany. It is, of course, about some elements of the Renaissance, certain humanistic phenomena and processes (Lytvynov, 2000). This was reflected not least in the combination of pedagogical ideas with religious issues, protection of Orthodoxy.

In the Ukrainian version of humanistic pedagogy, the moral-ethical and pedagogical ideas of the West European Renaissance were found. Being well-educated people and relying on the ancient philosophical tradition, Ukrainian intellectuals and teachers paid much attention not only to the issue of faith, but also to the issues of human life, cultivation of moral virtues (Ukrayinski humanisty epokhy Vidrodzhennia, 1995). Like European thinkers, they believed that the value of human presupposed high moral qualities, reasonableness and education rather than generosity, aristocracy and wealth.

West European education of that time was formed mainly by Jesuit colleges and schools. In the late 16th-the early 17th century, there was the golden age of Latin education. Jesuit schools were well-organized, with universal educational programmes and a well-thought system of pressure on people's consciousness. There was also a single statute of Jesuit schools that regulated their structure, determined the exact subordination of the school network of Jesuit institutions in Rome, obliged to control professors and students, to accept new pupils, to arrange exams, etc. The result of the activities of Jesuit schools and colleges in Ukraine and Europe was dissemination of a similar school culture with compulsory teaching mathematics, philosophy and theology. In their activities, Jesuit schools and colleges were guided by the model of a humanistic school, which was developed before the Protestant Gymnasium. Naturally, the system of Latin education was formed in Ukraine that synthesized the achievements of humanism and the Reformation.

At the same time, the processes that took place in the Ukrainian spiritual life of the 16th-17th century contributed to dissemination of Orthodox education and knowledge. A powerful cultural and national movement that began through the Polish-Catholic expansion and the introduction of the Union required educated and cultural people who could competently conduct polemics with Jesuits trained in Polish schools and colleges who were taught to conduct philosophical and religious disputes (Petruk, 2014).

In the 16th-17th centuries, educational centers were courtyards of the great Ukrainian magnates such as K. Ostrozkyi, Y. Zamoiskyi et al., where the cultural, intellectual and educational potential of the Ukrainian community - poets, didaskals, scribes and spiritual persons - was concentrated. The most famous one was the cultural and educational center formed around Prince Kostiantyn Ostrozkyi. There was opened the first high school in Ukraine, which contemporaries called "three-language lyceum", "college", "academy" (“Akty, otnosiashchiiesia k istorii Zapadnoi Rosii, 1851).

The archive of the academy, unfortunately, is lost. Therefore, its internal structure, the system and the subjects taught can only be researched due to the mediated data and the 
study of similar modern educational institutions. Apparently, the model of the school organization was based on Catholic and Protestant schools of Rzeczpospolita. The activities of such schools involded a traditional study of seven "free sciences", the so-called "trivium" (grammar, rhetoric and dialectics) and "quadrivium" (arithmetic, geometry, music, astronomy). However, the Ostroh School differed from existing European schools, including Polish ones, by an active use of Greek Byzantine cultural heritage and a distinctly national character. Due to the need to protect the national foundations of existence, the peculiarity of this school functioning consisted in the humanistic idea of the Trinitarian Lyceum, that is, Hebrew-Greek-Latin. The recognition of belonging to the Orthodox world led to replacement of the Hebrew with the Church Slavonic language (Isaievych, 1995).

As known, the idea of a trilingual school and a trilingual education in connection with the need for interpretation and publication of the Bible was first put forward by the prominent German humanist Erasmus of Rotterdam. On the grounds of the Erasmus functioned ideal schools and universities of Western Europe. The Collegium Trilingue (1517) established at Louvre University, France, and a similar college in Paris, later known as the famous College de France, were the most striking examples. In general, the study of Hebrew and Greek was a widespread phenomenon in Europe in the 16th and 17th centuries.

One can assume that the idea of the trilingual lyceum served as a prototype of the Ostroh School. It was preceded by appearance of the first printed Bible in the Church Slavonic language (Ostroh, 1581) and Bukvar (1578). The Greek Church Slavonic Bukvar is actually an elementary textbook of two languages with the Ostroh linguistic triad. In 1581, they published another school edition titled "Andriy Rimsh Chronology" that is a list of names of months in the Church Slavonic, Hebrew and Ukrainian languages. Each of them was added a verse to the story of the Old Testament.

Since 1583, the Ostroh School was called Academy. Its first rector was the famous Ukrainian scribe Herasym Smotrytskyi; there worked a plethora of outstanding, highly educated personalities of that time - Ukrainians and foreigners, whose pedagogical experience was formed at European universities. The graduate of the Ostroh Academy Meletii Smotrytski created one of the best works of linguistics - the Church Slavonic Grammar (Smotrytskyi, 1979). The well-known poet Demian Nalyvaiko was engaged in standardization of the Ukrainian literary language, who consistently accompanied Church Slavonic texts with translations into Ukrainian. The linguistic principles developed in Ostroh were creatively used in the Lviv Brother School. For printing needs in Ostroh there was also founded a printing house. Some editions intended for elementary school (Church Slavonic and Greek primers, Catechism) were prepared by teachers. The nature of cultural and publishing activities, of course, required a high level of erudition, which led to concentration of "knowledgeable" people in the Academy (Krypiakevych, 2002).

At the end of the 16th century, Ostroh became the place where brilliant intellectual powers united, made a great progress in development of Ukrainian education and ensured synthesis of the national and European educational traditions.

The Ostroh Academy and Ostroh scribes largely influenced development of higher schools in Ukraine, particularly in Volhynia. Graduates of the Academy worked as teachers in many schools. Fruitful ties were maintained with brother schools, especially the Lviv Btother School. In Lviv, there was founded a second after Ostroh Ukrainian school of higher type (Akty, otnosiashchiiesia $\mathrm{k}$ istorii Lvovskaho stavropihialnogo bratstvsa, 1904). Some of brother didaskals graduated from the Ostroh Academy. The traditions of Ukrainian schooling cultivated in Ostroh were taken over by Kyiv, where two schools, namely brother and Lavra, emerged. 
After the death of the Prince of Ostroh, the Academy decayed and became a Jesuit college, however the developed school system based on the combination of Ukrainian Byzantine traditions and achievements of European pedagogy largely determined the state of Ukrainian education in the future.

Significant influences of the European education system are also evident in the activities of the Zamois Academy (the late 16th - the early 17th century). Its organizer was the famous aristocrat and humanist Prince Jan Zamoiskyi. Famous Polish (Shimon Shimonovich, Yakub Gavatovich, Jan Schasny-Herbut) and Ukrainian humanists (Kasiian Sakovich, Sylvester Kosiv, Isaiah Trokhovych-Kozlovskyi) taught in the Zamois Academy.

The Zamois Academy was characterized by a high level of teaching, a rich library and had every reason to equate to the best European universities. The educational programme was dominated by the ideas of "humanistic ciceronism" and, most importantly, tolerance. There was opened a printing house and humanities were taught. During its existence, the Zamois Academy became a school for training scientific and educational staff both for Western European universities and the Kyiv-Mohyla Collegium (Krypiakevych, 2002).

\section{CONCLUISIONS}

Historical facts on existence and the nature of schools activities during the 16th-17th centuries prove the European level of education that was typical of Ukrainian schools and academies. The education system in Ukraine was created according to Western European models, and, in particular, Polish schools. Therefore, clarifying the social and cultural status of Ukrainian pupils and students, it is advisable to compare Ukrainian schools with Polish ones. Ukrainian schools of the 16th-17th centuries became a part of the pan-European educational space formed by the humanistic consciousness and pedagogical thought of the Renaissance. In Ukraine, the system of European educational and cultural values was historically formed.

The study on the history of formation of humanistic pedagogy and school education in Ukraine outlines possible perspectives for development of a modern Ukrainian school on the path to a unified pan-European educational space. The reputation of humanities, profound education, knowledge of European languages and high intellectual culture propagated by humanists remain models for today's generation of Ukrainian teachers and instructors.

\section{REFERENCES}

1. Grigorivich, I. \& Tarnavo-Borichevskiy, I. P. (1853). Akty, otnosiashchiesia $k$ istorii Zapadnoi Rossii (T. 1-5). Saint Petersburg: Tipografiya Eduarda Pratsa.

2. Isaievych, Ya. (1995). "Lycaeum Trilingue": kontseptsiya humanistychnoi shkoly v Yevropi. Ostrozka davnyna, 1, 8-12.

3. Krypiakevych, I. (2002). Istoriia ukrayinskoi kultury (T. 1-5). Kyiv: Naukova dumka.

4. Lytvynov, V. (2000). Renesansnyi humanizm v Ukraini. Kyiv: vyd. "Osnovy".

5. Petruk, N. (2014). Educational thought of Ukraine and Poland within Renaissance culture: from the history of intellectual discourse of XVI-XVII centuries. Comparative Professional Pedagogy, 4 (4), 33-38.

6. Petrushevich, A. S. (1880). Akty, otnosyashchiesya k istorii Lvovskago stavropigialnoho bratstva. Vremennik Stavropigiyskogo Instituta, 137-148.

7. Shynkaruk, V. (1988). Pamiatky bratskykh shkil na Ukraini: kinets XVI-pochatok XVII st.: teksty i doslidzhennia. Kyiv: Naukova dumka.

8. Smotrytskyi, M. (1979). Hramatyky slovenskiia pravylnoe syntahma. (1619). Kyiv: Naukova dumka.

9. Ukrayinski humanisty epokhy Vidrodzhennia. (1995). Kyiv: "Naukova dumka", vyd. "Osnovy".

10. Zyzanii, L. (1980). Hramatika slovenska. - Vilno, 1590. Kyiv: Naukova dumka. 